\title{
Changes in the $5-\mathrm{HT} 2_{A}$ receptor system in the pre-mammillary hypothalamus of the ewe are related to regulation of $\mathrm{LH}$ pulsatile secretion by an endogenous circannual rhythm Philippe Chemineau*1, Agnès Daveau ${ }^{1}$, Jean Pelletier ${ }^{1}$, Benoît Malpaux ${ }^{1}$, Fred J Karsch ${ }^{2}$ and Catherine Viguié $e^{2,3}$
}

\author{
Address: ${ }^{1}$ Equipe de Neuroendocrinologie et Maîtrise des Fonctions Saisonnières, Unité de Physiologie de la Reproduction et des Comportements, \\ UMR INRA-CNRS- Univ. F. Rabelais, 37380 Nouzilly, France, ${ }^{2}$ Reproductive Sciences Program and Department of Physiology, University of \\ Michigan, Ann Arbor, Michigan 48109-0404, USA and ${ }^{3}$ Present adress: UMR 181, INRA-ENVT 23 chemin des Capelles, 31076 Toulouse, France \\ Email: Philippe Chemineau* - Philippe.Chemineau@tours.inra.fr; Agnès Daveau - Agnes.Daveau@tours.inra.fr; \\ Jean Pelletier - jzz.pelletier@wanadoo.fr; Benoît Malpaux - Benoit.Malpaux@tours.inra.fr; Fred J Karsch - fjkarsch@umich.edu; \\ Catherine Viguié - c.viguie@envt.fr \\ * Corresponding author †Equal contributors
}

Published: 28 January 2003

BMC Neuroscience 2003, 4:I

This article is available from: http://www.biomedcentral.com/|47|-2202/4/I

(C) 2003 Chemineau et al; licensee BioMed Central Ltd. This is an Open Access article: verbatim copying and redistribution of this article are permitted in all media for any purpose, provided this notice is preserved along with the article's original URL.

\begin{abstract}
Background: We wanted to determine if changes in the expression of serotonin $2 \mathrm{~A}$ receptor $\left(5 \mathrm{HT2}{ }_{\mathrm{A}}\right.$ receptor) gene in the premammillary hypothalamus are associated with changes in reproductive neuroendocrine status. Thus, we compared 2 groups of ovariectomized-estradioltreated ewes that expressed high vs low LH pulsatility in two different paradigms ( 2 groups per paradigm): (a) refractoriness (low LH secretion) or not (high LH secretion) to short days in pinealintact lle-de-France ewes (RSD) and (b) endogenous circannual rhythm (ECR) in free-running pinealectomized Suffolk ewes in the active or inactive stage of their reproductive rhythm.

Results: In RSD ewes, density of $5 \mathrm{HT} 2_{\mathrm{A}}$ receptor mRNA (by in situ hybridization) was significantly higher in the high $\mathrm{LH}$ group $(25.3 \pm \mathrm{I} .4$ vs $2 \mathrm{I} .4 \pm \mathrm{I} .5$ grains/neuron, $\mathrm{P}<0.05)$ and ${ }^{3} \mathrm{H}$-Ketanserin binding (a specific radioligand) of the median part of the premammillary hypothalamus tended to be higher in the high group $(29.1 \pm 4.0 \mathrm{vs} 24.6 \pm 4.2 \mathrm{fmol} / \mathrm{mg}$ tissu-equivalent; $P<0.10)$. In ECR ewes, density of $5 \mathrm{HT} 2_{\mathrm{A}}$ receptor $m R N A$ and ${ }^{3} \mathrm{H}-$ Ketanserin binding were both significantly higher in the high LH group ( $20.8 \pm 1.6$ vs $17.0 \pm 1.5$ grains/neuron, $P<0.01$, and $19.7 \pm 5.0$ vs $7.4 \pm 3.4 \mathrm{fmol} /$ $\mathrm{mg}$ tissu-equivalent; $\mathrm{P}<0.05$, respectively).

Conclusions: We conclude that these higher $5 \mathrm{HT} 2_{\mathrm{A}}$ receptor gene expression and binding activity of $5 \mathrm{HT} 2 \mathrm{~A}$ receptor in the premammillary hypothalamus are associated with stimulation of LH pulsatility expressed before the development of refractoriness to short days and prior to the decline of reproductive neuroendocrine activity during expression of the endogenous circannual rhythm.
\end{abstract}

\section{Background}

Seasonal reproductive activity is a common feature of many mammalian species of temperate latitudes [1]. In ewes, ovulatory activity is suppressed for several months in spring and summer during the anestrous period. These seasonal changes in ovulatory activity result from changes in LHRH and LH pulsatile secretion [2,3]. Seasonality of neuroendocrine reproductive activity in ewes is under the 
control of an endogenous circannual rhythm [4-6] synchronized by photoperiod through its control of the circadian rhythm of melatonin secretion $[7,8]$. Expression of the endogenous circannual rhythm can be observed under two types of experimental conditions : prolonged exposure to constant photoperiod (i.e. constant duration of melatonin secretion) or elimination of melatonin secretion by pinealectomy. In the case of pineal-intact ewes exposed to constant short days following constant inhibitory long days, three successive phases of reproductive neuroendocrine activity can be distinguished: (a) initially, a short-day induced stimulation of LH pulsatile activity after a time-lag of about 45 days, (b) second, inhibition of LH pulsatility, resulting from «refractoriness» to short days after about 150 short days [9], probably the initial event of the expression of the endogenous rhythm, and (c) third, circannual changes between periods of high and low LH pulsatility reflecting expression of the endogenous circannual rhythm [5]. In pinealectomized ewes that are functionally uncoupled from their photoperiodic environment, the endogenous circannual rhythm is expressed and induces alternations of periods of high and low LH pulsatility, which are not synchronous among ewes or in phase with the seasons $[8,10]$.

Basic mechanisms responsible for the generation and the expression of this endogenous rhythm are unknown. Several neuromediator systems, such as catecholamines and serotonin (5HT) [11,12] (review [13]), and neuroplastic remodeling of GnRH neurons $[14,15]$ seem to play a role in seasonal and photoperiodic regulation of LH pulsatile secretion. However, in most of these cases, it is not known whether these mechanisms are involved in the expression of the endogenous rhythm or whether they simply mediate the effect of photoperiod and melatonin. In the case of serotonergic pathways, however, it is clear that the serotonergic component plays a role in LH suppression during the refractory state to short days $[16,17]$. Indeed, systemic administration of serotonin antagonists can temporarily reverse the suppression of $\mathrm{LH}$ pulsatile secretion in ewes that are refractory to short days [18]. The use of specific antagonists, and especially ketanserin, led to the suggestion that $5 \mathrm{HT} 2{ }_{\mathrm{A}}$ receptors are probably involved in this inhibitory effect of serotonin [19]. The inhibition of LH pulsatile secretion during the establishment of refractoriness to short days is associated with changes in $5 \mathrm{HT} 2 \mathrm{~A}$ receptor binding capacities ( ${ }^{3} \mathrm{H}$-ketanserin binding activity) in specific area of the ventral hypothalamus [20]. Howev$\mathrm{er}$, it is worth noting that although an increase in $5 \mathrm{HT} 2_{\mathrm{A}}$ receptor binding capacities was expected during this period of low secretion to be consistent with the inhibitory role of serotonin, the contrary was found, i.e. an increased ${ }^{3} \mathrm{H}$-ketanserin binding. This specific hypothalamic area has been identified as the premammillary hypothalamus as confirmed by the expression at this site of $5 \mathrm{HT} 2_{\mathrm{A}}$ receptor mRNA [21].

Collectively, the foregoing observations prompted us to investigate whether $5 \mathrm{HT} 2_{\mathrm{A}}$ receptors in the premammillary hypothalamus may play a role in the expression of the endogenous rhythm. As an initial step, we have determined if expression of the $5 \mathrm{HT} 2_{\mathrm{A}}$ receptor gene in the premammillary hypothalamus changes during the course of expression of the endogenous rhythm independently of photoperiodic or melatonin influence. In addition, we have examined if transcriptional regulation of the $5 \mathrm{HT} 2 \mathrm{~A}$ receptor gene is associated with changes in binding capacities of this receptor. For this purpose, we employed in situ hybridization for mRNA of $5 \mathrm{HT} 2_{\mathrm{A}}$ receptor and binding of ${ }^{3} \mathrm{H}$-Ketanserin in the premammillary hypothalamus of ewes under two experimental conditions enabling the expression of the rhythm: (a) pineal-intact ewes that were either refractory or not to short days (RSD), and (b) pinealectomized ewes during either the active and inactive stages of their endogenous circannual rhythm (ECR) of reproductive neuroendocrine activity.

\section{Results \\ Experiment I: Refractoriness to short days}

Mean plasma LH during photoperiodic treatments varied as expected (Fig. 1) with low LH plasma concentrations during long days, high values resulting from the stimulatory effect of short days and low values during continued exposure to short days due to the establishment of a refractory state to short days. On the day before sacrifice, LH pulse frequency was significantly higher in the High group than in the Low group (mean \pm S.E.M. $2.83 \pm 0.40$ vs 0.50 \pm 0.22 pulses $/ 5$ hours, $\mathrm{P}<0.001)$.

In situ hybridization analysis for $5 \mathrm{HT} 2 \mathrm{~A}$ receptor mRNA revealed that the density of silver grains was significantly higher in the neurons of ewes from the High group (25.3 \pm 1.4 vs $21.4 \pm 1.5$ grains/neuron, $\mathrm{P}<0.05$ ). Overall distribution of neurons per class of number of grains was significantly different between the two groups $($ Chi2 $=52$, P $<0.0001$ ); neurons bearing more than 20 grains were more numerous in the High than in the Low group (Figure 2). An example of in situ hybridization $5 \mathrm{HT} 2{ }_{\mathrm{A}}$ receptor mRNA labeling is given in Figure 3.

${ }^{3} \mathrm{H}-$ Ketanserin binding was not significantly different between groups, but tended to be significantly higher in the High group than in the Low group $(29.1 \pm 4.0$ vs $24.6 \pm$ $4.2 \mathrm{fmol} / \mathrm{mg}$ tissue-equivalent; $\mathrm{P}<0.10$ ).

\section{Experiment 2: Expression of the endogenous circannual rhythm}

Endogenous LH cycles were desynchronized among ewes and appeared to free run in all ewes included in the 

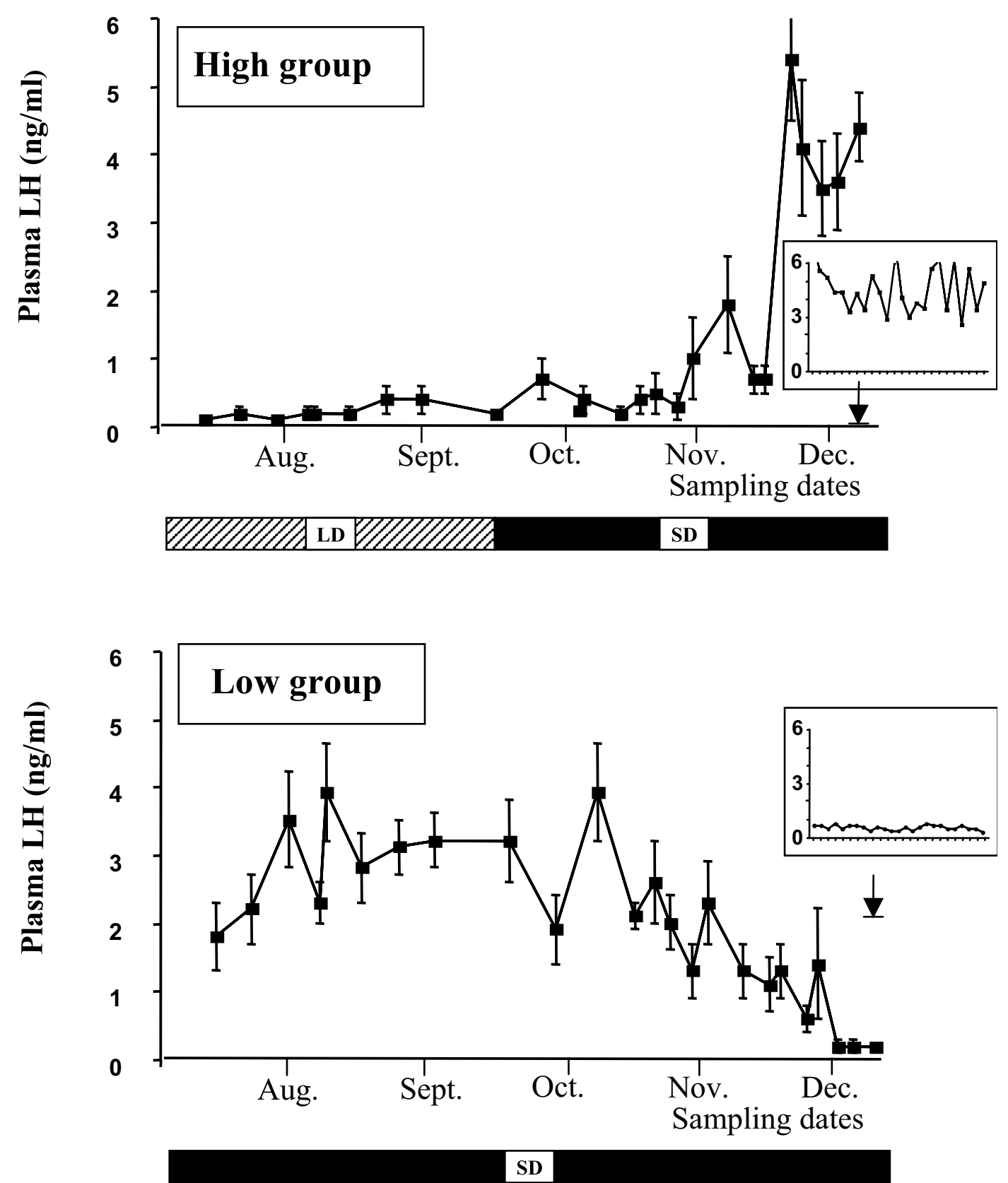

Figure I

Experiment I (RSD): Mean ( \pm SEM) plasma LH concentration in 2 groups of ovariectomized estradiol-treated lle-de-France ewes subjected to the artificial photoperiodic regimens indicated by the horizontal bars. High ewes $(n=6$; upper graph) were subjected to 3 months of short days (8L: 16D; April to July, data not shown) -3 months of long days (I6L: 8D, July to October), and 3 months of short days (8L: I6D, October to January). Low ewes $(n=6)$ were subjected to 3 months of long days (April to July, data not shown), and 6 months of short days (July to January). Inserts depict representative LH pulsatile secretory profiles the day before sacrifice (blood sampled every 12 min for 5 hours). 


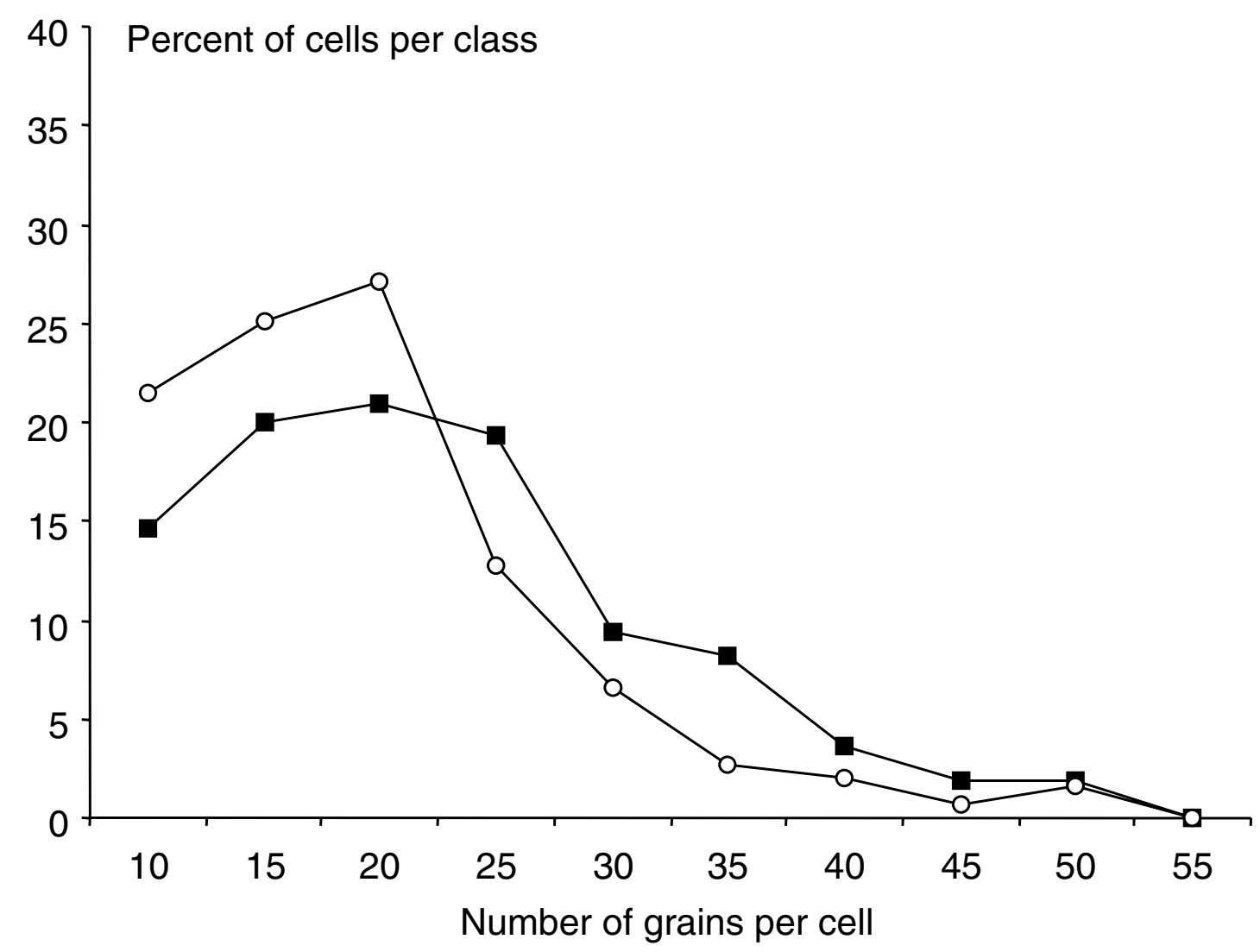

\section{Figure 2}

Frequency distribution of labelled neurons in frontal brain sections after in situ hybridization with riboprobes against sheep $5 \mathrm{HT} 2_{\mathrm{A}}$-receptor, according to the number of silver grains per neuron, in the premammillary hypothalamus of Ile-de-France ewes during the establishment of refractoriness to short days (experiment I). Closed and open symbols depict ewes with high or low LH pulsatile activity, respectively.

analysis [for more details see ref. [10]]. Figure 4 illustrates the LH profiles for one ewe in the High and Low groups; data were not pooled for presentation of mean values because the circannual LH cycles were not synchronized among ewes. On the day before sacrifice, LH pulse frequency was significantly higher in the High group than in the Low group $(3.50 \pm 0.72$ vs $0.83 \pm 0.40$ pulses $/ 4$ hours, $\mathrm{P}<0.01)$. One ewe which was detected as being high with the cluster cycle detection algorithm, did not show a high pulsatile activity ( 1 pulse/5 hours); this animal was included in the analysis as she had high overall LH values.

Expression of $5 \mathrm{HT} 2_{\mathrm{A}}$ receptor gene was different between groups. Density of silver grains was significantly higher in the neurons of ewes from the High compared to the Low group $(20.8 \pm 1.6$ vs $17.0 \pm 1.5, \mathrm{P}<0.05)$. Overall distribution of neurons classified by number of grains per neuron was significantly different between the two groups (Chi2 $=52, \mathrm{P}<0.0001$ ); neurons bearing more than 20 grains were more numerous in the High as compared with the Low group (Figure 5).

${ }^{3} \mathrm{H}$-Ketanserin binding in the premammillary hypothalamus was significantly higher in the High group than in the Low group $(19.7 \pm 5.0$ vs $7.4 \pm 3.4 \mathrm{fmol} / \mathrm{mg}$ tissue-equivalent; $\mathrm{P}<0.05)$. An example of $3 \mathrm{H}$-Ketanserin binding sites on sections of the premammillary hypothalamus is shown in Figure 6. 

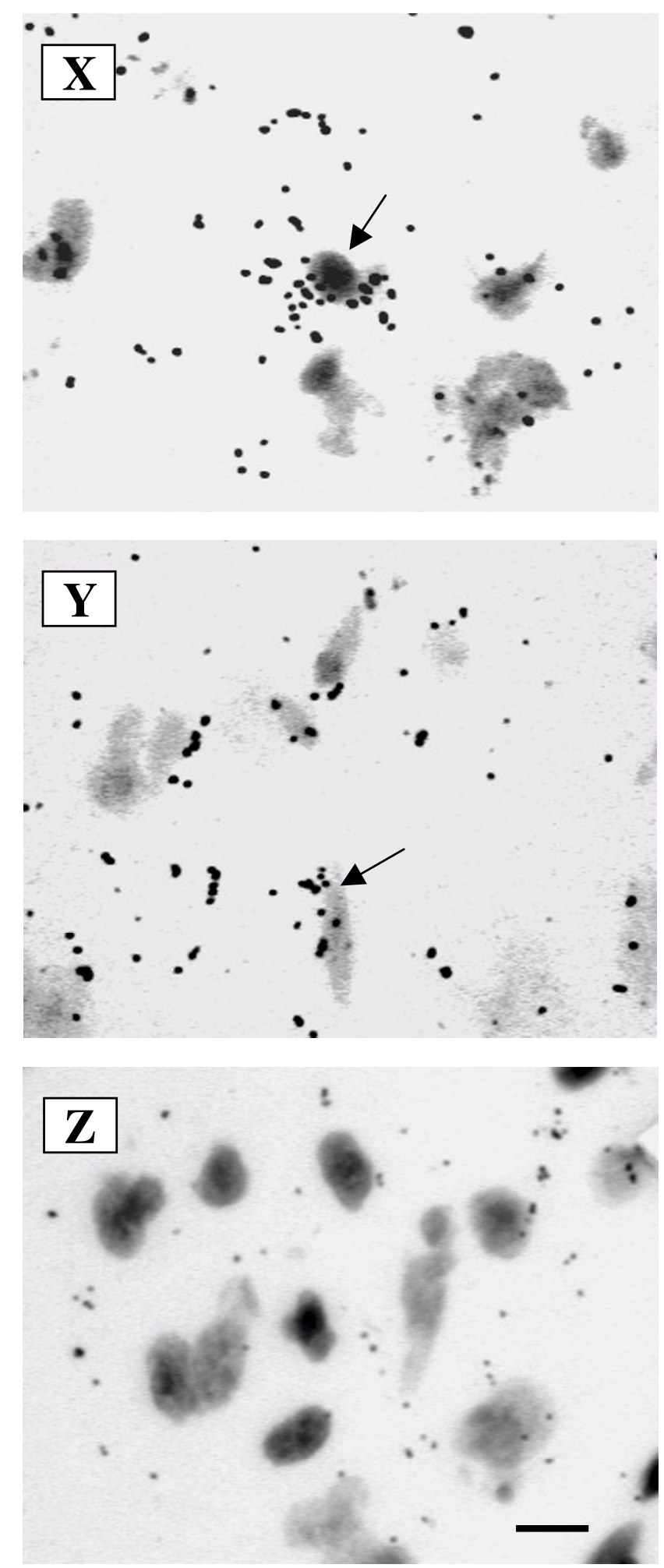

\section{Figure 3}

Bright-field microscopy images of premammillary hypothalamus after in situ hybridization with antisense (X, Y) or sense $(Z)$ riboprobes against sheep 5 HT2A receptor. Arrows indicate labeled neurons. Scale bar I5 $\mu \mathrm{m}$. $X$ is a ewe from the high group while $Y$ is a ewe from the low group. 

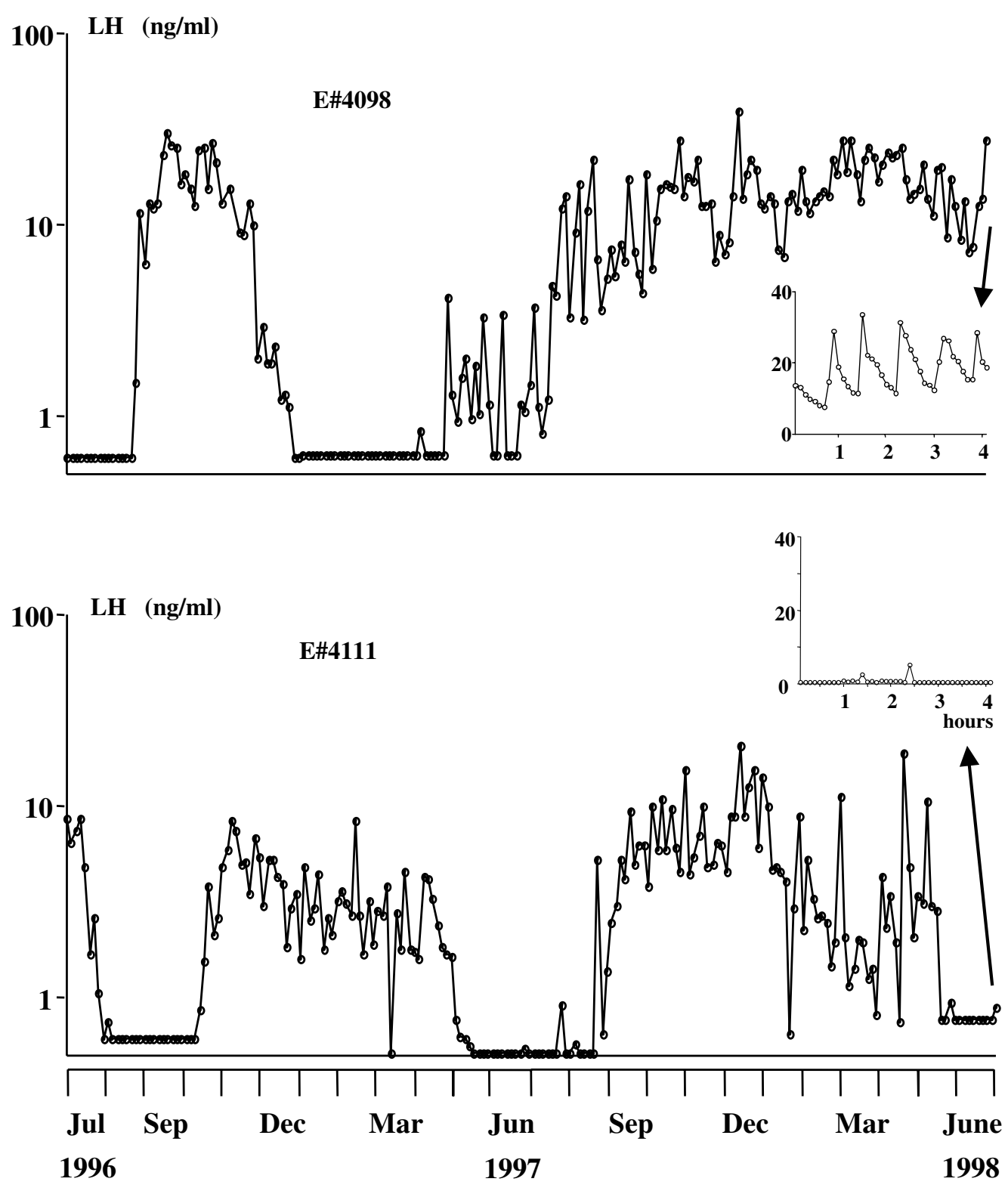

\section{Figure 4}

Experiment 2 (ECR): plasma LH concentration measured in bi-weekly blood samples obtained from two pinealectomized Suffolk OVX+E ewes. Animals were maintained melatonin-free under simulated natural photoperiodic conditions in a light-proof building for 2 years. The upper graph depicts LH profiles in one ewe in the High stage of the endogenous rhythm at the end of the experiment and the lower graph LH profile of one ewe in the Low stage. Inserts depict LH pulsatile secretory profiles at the end of the experiment (blood sampled every 6 min for 4 hours). 


\section{Discussion}

Coordinated changes in the expression of the $5 \mathrm{HT} 2 \mathrm{~A}$ receptor gene and in the density of $5 \mathrm{HT} 2 \mathrm{~A}$ receptors were observed in the premammillary hypothalamus; both gene expression and binding activity were greater in ewes expressing a high LH pulsatile secretion compared to those expressing a low LH pulsatile secretion. This relationship was observed both during the establishment of refractoriness to short days (RSD) and during the course of the endogenous circannual rhythm (ECR) of neuroendocrine activity. The results obtained with ketanserin binding, in ewes refractory or not to short days (experiment 1 ) tended to be significant, this tendency confirms earlier results obtained in the same breed of ewes, placed in the same experimental conditions [20]. Our current results brought interesting new insights by showing that this increase in binding capacity results at least in part from an up-regulation of expression of the $5 \mathrm{HT} 2 \mathrm{~A}$ receptor gene.

It is important to emphasize that the two experiments described here were conducted in two different locations (France and USA), in two different seasonal breeds of sheep (Ile-de-France and Suffolk), and using two different animal models (pineal-intact ewes maintained in short days and pinealectomized ewes under normal photoperiodic changes). Yet, the results were comparable regarding changes in the $5 \mathrm{HT} 2{ }_{\mathrm{A}}$ receptor system in the premammillary hypothalamus according to $\mathrm{LHRH} / \mathrm{LH}$ pulsatile activity. The observation that expression of the gene and density of receptors varied in the same direction in both experiments (even if a non-significant tendency in the binding density was observed in the RSD experiment) is of major importance. This provides strong evidence that the enhanced activity of the $5 \mathrm{HT}_{2}$ receptor system in ewes expressing stimulated $v$ s inhibited LH pulsatility can occur in the absence of daily changes in melatonin input and thus photoperiodic influence. This suggests one or two possibilities. Either (a) the changing activity of the $5 \mathrm{HT} 2 \mathrm{~A}$ receptor system is the consequence of changes in the LHRH/LH pulse generating mechanisms, or (b) changes in the $5 \mathrm{HT} 2 \mathrm{~A}$ receptor system are a fundamental component of the circannual processes that cause changes in LHRH/LH pulsatility. In this case, the establishment of refractoriness to short days could be considered as an early step in expression of the endogenous circannual rhythm [5], and changes of activity in the $5 \mathrm{HT} 22_{\mathrm{A}}$ receptor system could be considered as part of the endogenous mechanisms involved in circannual rhythms of reproductive neuroendocrine activity.

At present, it is not known whether changes in the $5 \mathrm{HT} 2 \mathrm{~A}$ receptor system are a cause or a consequence of the circannual rhythm of LHRH and LH secretion. Nevertheless, it is of interest to consider a causal relationship and, for this purpose, it is useful to consider certain parallel- isms between circadian and circannual mechanisms. Regarding circadian rhythms, three major points could be raised : (a) The suprachiasmatic nucleus is the brain area where the master circadian clock is located, and where several «clock» genes are expressed at different precise times of the cycle (reviews [22] and [23]). (b) Serotonergic fibers project from raphe nuclei to the suprachiasmatic nucleus [24], onto $5 \mathrm{HT} 1_{\mathrm{B}}$ receptors [25], probably to modulate response of the suprachiasmatic nucleus activity to light stimulation [26]. (c) The suprachiasmatic nucleus is the nucleus where photoperiodic and/or light inputs act to synchronize the circadian system to fit with the external environment, directly via nerve fibers and/or by the way of melatonin receptors (review [23]).

How might these three points relate to the circannual rhythms? (a) In contrast with circadian rhythms, there is to date no formal identification of a site for a clock driving circannual rhythms. In the ground squirrel, which was extensively studied in this context [27-33], a brain site involved in generation of circannual cycles was not discovered. (b) With respect to serotonergic innervation, medium or high density of serotonin fibers are present in the premammillary hypothalamus in sheep [34], whitefooted mouse [35], monkey [36] and rat [37,38]; these fibers probably originate from the raphe nuclei, as in the cat [39]. Changes in gene expression and ketanserin binding capacities of $5-\mathrm{HT} 2_{\mathrm{A}}$ receptor in the pre-mammillary hypothalamus of the ewe were observed in the present study. (c) Finally, the site in which we observed changes in $5 \mathrm{HT} 2 \mathrm{~A}$ receptor seems to be located in the same area than the site of action of melatonin to stimulate LHRH/ LH pulsatile secretion in the ewe [40], probably via MT1 receptors $[41,42]$. This stimulation of the LHRH pulsatility by melatonin may be one way by which melatonin enters the circannual system to synchronize it to the photoperiodic cue of the outside environment [review [43]]. This may explain that in the results presented here, ewes in the absence of any photoperiodic/melatonin input, expressed de-synchronized rhythmicity of LH secretion. Thus, the suprachiasmatic nucleus contains a circadian clock and is the site where the external cues are treated to reset the clock via melatonin receptors or/and via serotonergic system, and the premammillary hypothalamus may give rise (or help give rise) to circannual rhythmicity and may be a site where melatonin synchronizes the endogenous circannual rhythm and where changes in the serotonergic system take place.

The involvment of the posterior hypothalamus in reproductive function has received relatively little attention in the rat where it has only been shown to inhibit $\mathrm{LH}$ release and that it may participate in timing and amplitude of the pro-oestrus surge of the hormone [44]. In the macaque posterior hypothalamus, ovarian steroids altered expres- 


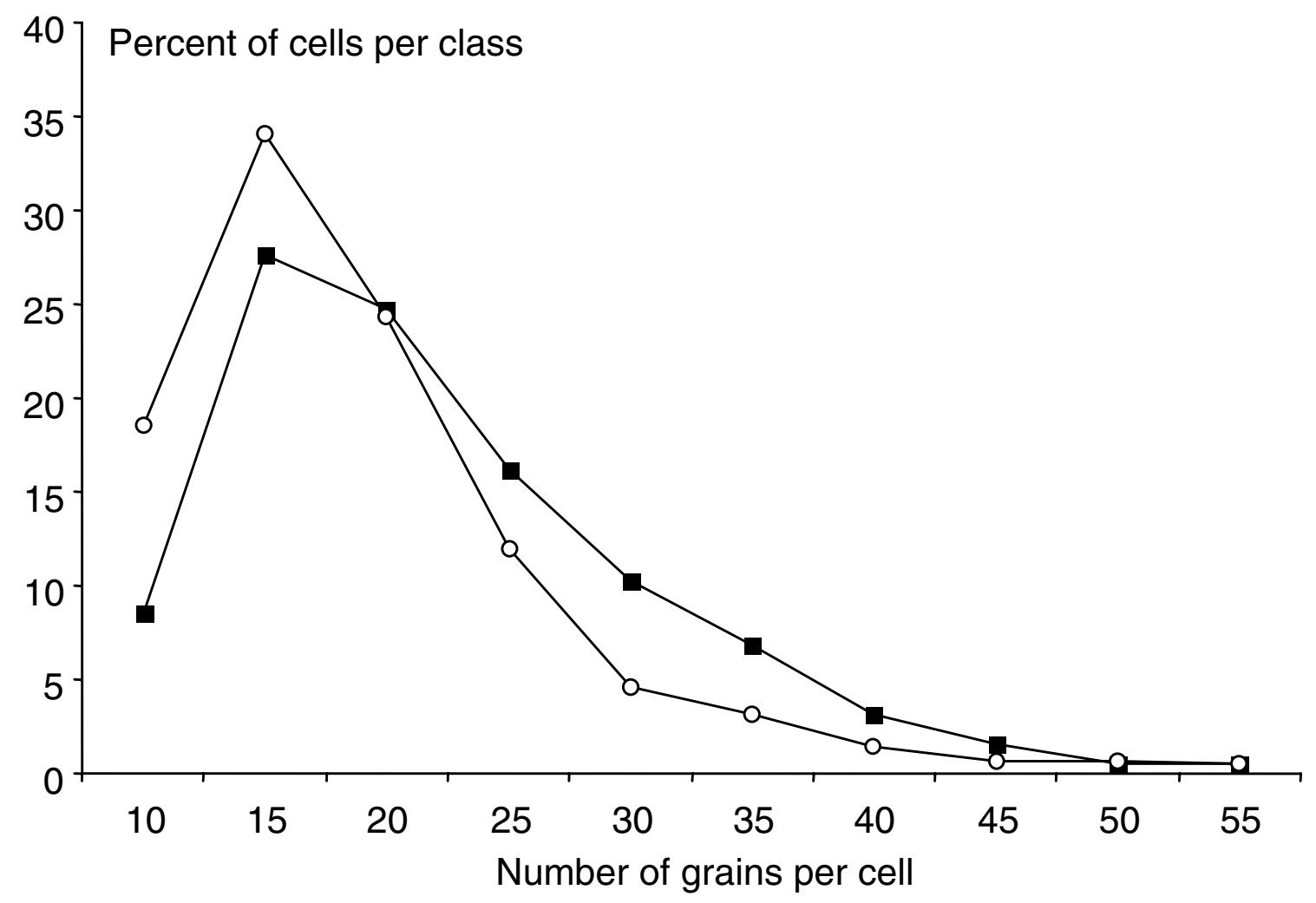

\section{Figure 5}

Frequency distribution of labelled neurons in frontal brain sections after in situ hybridization with riboprobes against sheep $5 \mathrm{HT} 2_{A}$-receptor, according to the number of silver grains per neuron, in the premammillary hypothalamus of pinealectomized Suffolk ewes at different stages of the expression of the endogenous circannual reproductive rhythm (experiment 2). Closed and open symbols depict ewes with high or low LH pulsatile activity, respectively.

sion of $5 \mathrm{HT} 2_{\mathrm{C}}$ receptor gene, but not of $5 \mathrm{HT} 2_{\mathrm{A}}$ receptor gene [45]. Recent preliminary observations in Suffolk ewes suggest that thyroid hormones, which are required for the expression of endogenous rhythms, may be required for the day-night rhythm of fos expression in the premammillary hypothalamus [46], which re-inforces the suggestion of a potential role of this particular structure in the mechanisms involved in the circannual endogenous rhythm of reproductive activity in sheep. More generally, the posterior hypothalamus is considered as playing an important role in the maintenance of circadian wakefulness, especially via its histaminergic neurons [39,38].
The divergent actions of serotonin are achieved through seven distinct families of receptors encoded by more than seven different genes, among them the previously mentionned $5 \mathrm{HT} 2_{\mathrm{A}}, 5 \mathrm{HT} 2_{\mathrm{B}}$ and $5 \mathrm{HT} 2_{\mathrm{C}}$ receptors, each of which exhibit subtypes or isoforms [reviews $[47,48]]$. How these different receptors mediate the multiple action of serotonin and whether individual neurons express multiple receptors are still subject of debate [review [48]]. In the present experiment, the riboprobes used were specific of the sheep $5 \mathrm{HT} 2 \mathrm{~A}$ receptor. They showed a low homology with $5 \mathrm{HT} 2_{\mathrm{B}}$ and $5 \mathrm{HT} 2_{\mathrm{C}}$ receptors $(60 \%$ for both), and no homology at all for other subtypes of recep- 
tors, as it was shown by Pelletier et al. [21]. This situation ensures that the mechanisms described here are specific of the ovine $5 \mathrm{HT} 2_{\mathrm{A}}$ receptors.

Regarding the functional role of $5 \mathrm{HT} 2 \mathrm{~A}$ receptors, in ovariectomized rats, they seem to be involved in the negative feedback of oestrogens on LH release [49] and in the triggering of LH surge by oestradiol [50]. As previously exposed, it was shown in ewes, that the use of specific antagonists of $5 \mathrm{HT} 2{ }_{\mathrm{A}}$ receptors liberates the inhibition of pulsatile LHRH/LH activity during refractoriness to short days $[18,19]$. However, this effect is contradictory with the results presented here showing that $5 \mathrm{HT} 2 \mathrm{~A}$ receptor gene expression and binding activity were lower during this specific stage. More generally, the information on the potential role of these $5 \mathrm{HT} 2 \mathrm{~A}$ receptors in mammals is scarce but suggests that they could be involved in depression [reviews [51,52]] and/or learning [53], which are both longterm neurobiological events. Regarding the interaction between $5 \mathrm{HT} 2{ }_{\mathrm{A}}$ receptor system and thyroid hormones, it is interesting to note that ${ }^{3} \mathrm{H}$-Ketanserin binding capacity, is decreased in thyroidectomized rats, and that this effect of thyroidectomy can be reversed with low doses of T4 [54]. Thus, the fact that, $5 \mathrm{HT} 2 \mathrm{~A}$ receptor activity in rats and the transition into anestrus in sheep [55-58], are dependent of thyroid hormones may suggest that it would be interesting to look for an eventual relationship between $5 \mathrm{HT} 2 \mathrm{~A}$ receptors and thyroid hormones in sheep.

\section{Conclusions}

In conclusion, we demonstrated in two different paradigms that the expression of a change in circannual rhytmicity in LHRH/LH neuroendocrine activity is associated with regulation of $5 \mathrm{HT} 2{ }_{\mathrm{A}}$ receptor gene expression in the premammillary hypothalamus of the ewe. This anatomical and molecular evidence for an implication of the $5 \mathrm{HT} 2$ A receptor system of the premammillary hypothalamus in circannual rhythmicity provides new insight in the field of circannual rhythms. In particular, the present findings provide novel evidence for a putative site that may contribute to the generation of endogenous circannual rhythms. This possibility is further strengthened by evidence that the premammillary hypothalamus could also be a site for integration of the circannual mechanisms with the melatonin signal which translates photoperiodic cues synchronizing the endogenous rhythm. Thus, our present results pave the way for studies to investigate the functional significance of the changes in $5 \mathrm{HT} 2 \mathrm{~A}$ receptor and of the premammillary hypothalamus as a component of circannual mechanisms.

\section{Methods}

\section{Animal model}

Two experiments were conducted on adult ovariectomized ewes treated with constant release estradiol im- plant $(1.7 \mathrm{~cm}$ for experiment 1 and $3 \mathrm{~cm}$ for experiment 2 ; [59]). In this model, plasma LH concentration in blood sampled twice a week provides a robust index of seasonal changes in reproductive neuroendocrine responsiveness to estradiol negative feedback on LHRH and LH pulsatile secretion [60]. High LH concentration reflects high frequency of LHRH and LH pulses, which is indicative of the breeding season, whereas low LH reflects infrequent LHRH and LH pulses typical of anestrus [61]. Animals were fed hay and pellets and had free access to water and mineral licks. Surgeries were performed under aseptic conditions.

\section{Experimental design}

Experiment I: Refractoriness to short days (RSD)

This study was conducted on 12 adult (3-7 years old) Ile de France ewes maintained at the INRA Research Center of Nouzilly France $\left(47^{\circ} \mathrm{N}\right)$. All ewes were housed in a lightproof building under artificial lighting (300 lux at animal eye level). Temperature was not regulated. Ewes were allocated to two groups ( $n=6 /$ group). The first group (high LH group) was exposed to short days (8L:16D) for 3 months starting in April; 3 months of long days (16L: 8D; July to October) and 3 months of short days (8L: 16D; October to January) after which brains were collected. With this photoperiodic regimen, ewes remain sensitive to the stimulatory effect of short days resulting in high pulsatile LH secretion at the time of sacrifice. The second group (low LH group) was exposed to long days for 3 months starting in April followed by 6 months of short days. This photoperiodic regimen enables the photorefractory state to occur resulting in low pulsatile LH secretion at the time of sacrifice. Blood samples were collected twice a week throughout photoperiodic treatments. LH pulsatile secretory profiles on the day before sacrifice were determined from LH concentration measured in blood samples collected every 12-min for 5 hours. Ewes from both groups were sacrificed in pairs by decapitation between 10:00 am and 2:00 pm on the same day. All procedures were performed in accordance with French legal requirements, and with the authorization for animal experimentation nb A37801 of the Ministry of Agriculture.

\section{Experiment 2: Endogenous circannual rhythm (ECR)}

Seventeen pinealectomized Suffolk ewes (of which 12 were used, see below) were maintained at the Sheep Research Facility near Ann Arbor, MI U.S.A. $\left(42^{\circ} 18^{\prime} \mathrm{N}\right)$. These ewes had previously been used in another experiment aimed at synchronizing their circannual reproductive rhythm by infusions of different melatonin patterns at specific periods of the circannual endogenous cycle [10]. Upon completion of that study, the ewes were made available to the present study. The ewes were pinealectomized in December 1994 during the late breeding season $[62,10]$ and housed in light-proof rooms where 

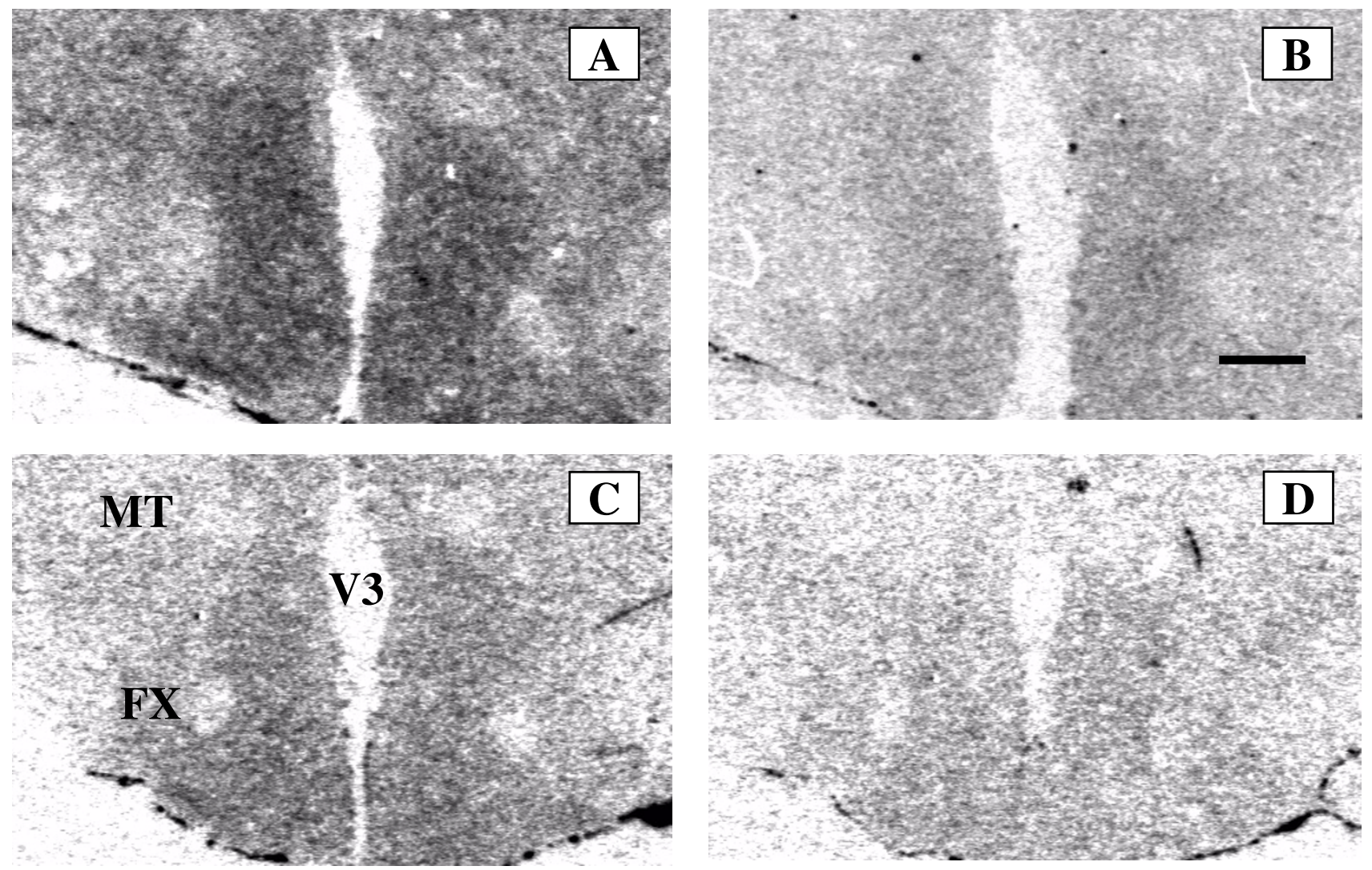

\section{Figure 6}

$[3 \mathrm{H}]$ ketanserin binding sites on coronal sections of premammillary hypothalamus from 2 representative ewes. $A$ and $C$ : total binding and $B$ and $D$ : remaining binding after incubation with $10-6 M$ methysergide. $A$ and $B$ are sections from a ewe exhibiting high LH pulsatility whereas $C$ and $D$ are from a ewe exhibiting low LH pulsatility. Bar $=2 \mathrm{~mm}$. FMT, mammillothalamic tract; FX, fornix. Third ventricule (V3).

lighting (350 lux at eye level) was adjusted twice a week to simulate natural photoperiod, including $60 \mathrm{~min}$ for civil twilight. Temperature was not regulated. Ewes were allocated to 3 groups, two of which received nightly i.v. infusion of physiological amounts of melatonin for 70 days/ year for two consecutive years [10]. Starting in July 1996, all the animals were not treated with melatonin for two consecutive years, to allow free running circannual cycles of pulsatile LHRH and LH secretion to be expressed. LH concentrations were determined in blood samples collected twice a week thoughtout the experiment and every 6min for 4 hours the day before sacrifice. At the end of the study (July 1998), all ewes were sacrificed by barbiturate overdose during daytime on the same day. Procedures were approved by the University of Michigan Committee on the Use and Care of Animals.

\section{Brain processing, in situ hybridization and autoradiography}

Brain processing

Following sacrifice, brains were rapidly removed, dissected out in several blocks and frozen on liquid nitrogen vapors (experiment 1 ) or by immersion in isopentane maintained at $-30^{\circ}$ in dry ice (experiment 2 ). Brains were used as fresh ones and were never perfused nor perifused before or after being removed from the skull. All blocks were stored at $-72^{\circ} \mathrm{C}$. Frozen frontal brain sections (15 $\mu \mathrm{m})$ were generated between the infundibular and premammillary recesses using a microtome-cryostat (Leitz 
Kryostat 1720 ) at $-20^{\circ} \mathrm{C}$ and were thaw-mounted on slides pretreated with $1 \% 3$-aminopropyltriethoxysilane (Aldrich Chemical Co, Saint-Quentin, France) in acetone as indicated by Sibony et al. [63]. Consecutive sections were used for in situ hybridization and autoradiography sections for in situ hybridization were post fixed by immersion for $10 \mathrm{~min}$ at $4{ }^{\circ} \mathrm{C}$ in $4 \%$ paraformaldehyde in phosphate buffer ( $0.1 \mathrm{M}, \mathrm{pH} 7.4)$, washed in $4 \times \operatorname{SSC}(4 \mathrm{x}$ sodium citrate $0.15 \mathrm{M}$, sodium chloride $1.2 \mathrm{M}$ ), dried under an air-stream, and stored at $-20^{\circ} \mathrm{C}$. Sections for autoradiography were stored at $-20^{\circ} \mathrm{C}$ immediately after sectioning.

After in situ hybridization, brain sections were stained with neutral red $0.1 \%$ (Fluka, Sigma Aldrich, Switzerland) for histological verification and compared with the ewe atlas of Richard [64] and with the rat atlas of Paxinos and Waston [65].

\section{In situ hybridization}

In situ hybridization was performed as described by Pelletier et al. [21]. Sense and antisense strand riboprobes (546 bp) were obtained from two clones containing the sheep $5 \mathrm{HT} 2_{\mathrm{A}}$ receptor $\mathrm{CDNA}$ insert in the opposite section. The two constructs were linearized by HindIII and the transcripts were generated using $\mathrm{T} 7$ polymerase in the presence of ${ }^{35}$ S-UTP (Amersham, UK). Free nucleotides were separated from labelled probes by filtration through a 1 $\mathrm{ml}$ Sephadex G50 column previously equilibrated with 20 micrograms tRNA dissolved in TED buffer (10 mM TRIS, $1 \mathrm{mM}$ ED-TA, $10 \mathrm{mM}$ dithiothreitol).

Series of slices were treated by pairs of one ewe from each group. In situ hybridization labelling was performed according to Sibony et al. [63] modified as follows: each section was incubated with 19 microlitters hybridization solution containing approximately $200000 \mathrm{dpm}$ sense or antisense riboprobe and was treated with Rnase (10 micro litters/ml) for $1 \mathrm{~h}$ at $37^{\circ} \mathrm{C}$.

After different washings [63], sections were air dried and coated with a liquid NBT2 emulsion (Kodak, Integrabiosciences, Eaubonne, France) diluted twice with sterile demineralized water, and exposed for 6 weeks.

The number of silver grains per neuron marked in the premammillary hypothalamus was counted with a computerized image-analysis system (Biocom Histo 500, Les Ulis, France). A cell was considered as positively labeled if it contained at least 5 silver grains. A minimum number of 100 labeled neurons was recorded for each ewe distributed on both sides of the third ventricle. All sections were included in an area which fitted the maximum of ${ }^{3} \mathrm{H}$-Ketanserin binding sites [20] and of silver grains in in situ hybridization with the same probes [21]. All determinations were done under blind observations. Results are expressed as the mean number of silver grains per neuron and as the distribution of neurons per class of number of silver grains.

\section{Autoradiography for ${ }^{3} \mathrm{H}$-Ketanserin binding studies}

Autoradiographies were perfomed as described by Le Corre et al. [20]. Six pairs of animals (each pair with one ewe from each group) were constituted at random. Incubation conditions for ${ }^{3} \mathrm{H}$-Ketanserin were performed according to Pazos et al. [66]. Briefly, slide-mounted tissue sections were preincubated for $15 \mathrm{~min}$ in $0.17 \mathrm{M}$ Tris-HCl ( $\mathrm{pH}=7.7$ ) buffer at room temperature. After dripping, the sections were incubated for $2 \mathrm{~h}$ at room temperature with $3 \mathrm{nM}^{3} \mathrm{H}$-Ketanserin $(64.1 \mathrm{Ci} / \mathrm{mmol})$ in $0.4 \mathrm{ml}$ preincubation buffer on each section. The incubation was terminated by washing the sections twice for $5 \mathrm{~min}$ in ice-cold preincubation buffer $\left(4^{\circ} \mathrm{C}\right)$. The non-specific binding was defined in the presence of $10^{-6} \mathrm{M}$ methysergide. At the end of the washing period, tissues were dried with a stream of air. Sections and tritiated standards (specific activity 0.06$35 \mathrm{nCi} / \mathrm{mg}$ tissue equivalent, Amersham, France) were then placed in X-ray cassettes and apposed to Hyperfilm $\left[{ }^{3} \mathrm{H}\right]$ (Amersham, France) for 4 weeks at $-72^{\circ} \mathrm{C}$. Films were developed in D19 (Kodak) for $6 \mathrm{~min}$ at room temperature, rapidly rinsed with running water, fixed for 20 min (AL4, Kodak) and washed with distilled water.

Quantitative determination of ${ }^{3} \mathrm{H}$-Ketanserin binding sites were performed using densitometric measurements of autoradiographs with the computerized image-analysis system (Biocom). Reference curves derived from the $\left[{ }^{3} \mathrm{H}\right]$ standard were used to convert gray level readings into $\mathrm{fmol} / \mathrm{mg}$ tissue equivalent [67]. Multiple readings (4 to 8) were made in a tissue section and the mean optical density was measured from at least 4 sections per ewe. Non specific binding was similarly determined in adjacent sections. Specific binding was obtained by substracting nonspecific from total binding. All determinations were done under blind observations.

\section{LH assays and LH pulse identification}

In experiment $1, \mathrm{LH}$ was measured in duplicate in a double-antibody radioimmunoassay [68] as modified by Montgomery et al. [69]. The sensitivity of the assay was $0.1 \mathrm{ng} / \mathrm{ml}$ and the intra- and inter-assay coefficients of variation were 9.2 and $9.8 \%$, respectively. LH values are expressed in terms of CY-LH-S12. In experiment 2, LH was measured in duplicate in 10- to 200- $\mu$ l aliquots of serum using a modification [70] of a previously described radioimmunoassay $[71,72]$. LH values are expressed in terms of NIH-LH-S12. Assay sensitivity averaged $0.65 \pm$ $0.19 \mathrm{ng} / \mathrm{ml}$. Within and between assay coefficients of variation (CV) averaged $6 \%$ and $10 \%$, respectively. In both experiments, pulses were identified by an adaptation of 
the method described by Wallace and MacNeilly [73]. Briefly, a pulse was defined as a value exceeding $1 \mathrm{ng} / \mathrm{ml}$ of plasma that had a concentration greater than the mean of the two previous concentrations by at least 3 standard deviations. Standard deviation was estimated for each point from the mean intraassay coefficient of variation. If consecutive samples were identified as a pulse, only the one having the highest concentration was considered as a pulse.

In experiment 2, circannual LH cycles in each ewe were identified by a cluster cycle detection algorithm [74]. LH cycles were divided into high and low stages using a probability level of $5 \%$ or less to discriminate between contiguous clusters of high and low LH values. For analysis, ewes were allocated to the low or high group according to their neuroendocrine stage (low or high LH secretion) at the time of sacrifice as determined by the cluster analysis. Only ewes showing a well defined state using this algorithm were kept in the study (12 ewes, 6 with high LH and 6 with low LH).

\section{Statistical tests}

LH pulse frequency, and density labeling in in situ hybridization and binding density of ${ }^{3} \mathrm{H}$-Ketanserin were compared between groups using unpaired T-test. Distribution of neurons according to staining density was analyzed by the way of the $\mathrm{Chi}^{2}$ method. (Statview ${ }^{\circledast}$, Abacus Concept, Berkeley, Ca, USA).

\section{Authors' contributions}

All authors contributed equally to this work. PC, FJK \& CV conceived the study, and participated in its design and coordination. PC \& AD followed experiment 1. AD carried out brain preparation, the autoradiographic and in situ hybridization studies, and the radioimmunoassays of experiment 1 . FJK \& CV followed experiment 2 and perfomed the radioimmunoassays; $\mathrm{CV}$ carried out brain preparation of experiment 2. JP provided the probes for in situ hybridization and gave technical advices for the tissue preparation. BM participated in the design of the study and in its interpretation. PC drafted the manuscript with $\mathrm{CV}$, FJK \& BM. All authors read and approved the final manuscript.

\section{Acknowledgements}

The authors wish to thank Graham K. Barrell and Lori A. Thrun for providing the use of circannual ewes in experiment 2; the staff in charge of the llede-France flock in Nouzilly and at the sheep research facility of the University of Michigan at Ann Arbor. They also want to thank C. Fagu, P. Vanbecaelere and C. Gauthier of the RIA laboratory in Nouzilly for performing the LH assay of experiment I, Marha Brown and assay facility from RSP; G. Niswender. L.O. Reuckert for supplying assay reagents.

\section{References}

I. Ortavant R, Pelletier J, Ravault JP, Thimonier J and Volland P Photoperiod: main proximal and distal factor of the circannual cycle of reproduction in farm mammals. Oxford Rev 1985 , 7:305-345

2. Karsch FJ, Bittman EL, Foster DL, Goodman RL, Legan SJ and Robinson JE Neuroendocrine basis of seasonal reproduction Recent Prog Horm Res 1984, 40:185-210

3. Barrell GK, Moenter SM, Caraty A and Karsch FJ Seasonal changes of gonadotropin-releasing hormone secretion in the ewe. Biol Reprod 1992, 46: I I30-1135

4. Malpaux B, Wayne NL and Karsch FJ Termination of the breeding season in the Suffolk ewe: involvement of an endogenous rhythm of reproduction. Biol Reprod 1988, 39:254-263

5. Karsch FJ, Robinson JE, Woodfill CJI and Brown MB Circannual cycles of luteinizing hormone and prolactin secretion in ewes during prolonged exposure to a fixed photoperiod: evidence for an endogenous reproductive rhythm. Biol Reprod 1989, 41:1034-1046

6. Malpaux B, Robinson JE, Wayne NL and Karsch FJ Regulation of the onset of the breeding season of the ewe: importance of long days and of an endogenous reproductive rhythm. J Endocrinol 1989, I 22:269-278

7. Woodfill CJ, Robinson JE, Malpaux B and Karsch FJ Synchronization of the circannual reproductive rhythm of the ewe by discrete photoperiodic signals. Biol Reprod 1991, 45: | | 0-121

8. Woodfill CJ, Wayne NL, Moenter SM and Karsch FJ Photoperiodic synchronization of a circannual reproductive rhythm in sheep: identification of season-specific time cues. Biol Reprod 1994, 50:965-976

9. Malpaux B, Robinson JE, Brown MB and Karsch FJ Reproductive refractoriness of the ewe to inductive photoperiod is not caused by inappropriate secretion of melatonin. Biol Reprod 1987, 36:1333-134|

10. Barrell GK, Thrun LA, Brown ME, Viguié $C$ and Karsch FJ Importance of photoperiodic signal quality to entrainment of the circannual reproductive rhythm of the ewe. Biol Reprod 2000, 63:769-674

II. Meyer SL and Goodman RL Neurotransmitters involved in mediating the steroid-dependent suppression of pulsatile luteinizing hormone secretion in anestrous ewes: effects of receptor antagonists. Endocrinology | 985, I | 6:2054-206 |

12. Meyer SL and Goodman RL Separate neural systems mediate the steroid-dependent and steroid-independent suppression of tonic luteinizing hormone secretion in the anestrous ewe. Biol Reprod 1986, 35:562-57I

13. Thiéry JC, Chemineau P, Hernandez X, Migaud M and Malpaux B Neuroendocrine interactions and seasonality. Domest Anim Endocrinol 2002, 23:87-100

14. Xiong JJ, Karsch FJ and Lehman MN Evidence for seasonal plasticity in the gonadotropin-releasing hormone (GnRH) system of the ewe: changes in synaptic inputs onto GnRH neurons. Endocrinology 1997, 138:1240-1250

15. Viguié C, Jansen HT, Glass JD, Watanabe M, Billings HJ, Coolen L, Lehman MN and Karsch FJ Potential for polysialylated form of neural cell adhesion molecule-mediated neuroplasticity within the gonadotropin-releasing hormone neurosecretory system of the ewe. Endocrinology 200I, I 42:1317-1324

16. Whisnant CS and Goodman RL Further evidence that serotonin mediates the steroid-independent inhibition of luteinizing hormone secretion in anestrous ewes. Biol Reprod 1990, 42:656661

17. Kao C, Schaeffer DJ and Jackson GL Different neuroendocrine systems modulate pulsatile luteinizing hormone secretion in photosuppressed and photorefractory ewes. Biol Reprod 1992, 46:425-43

18. Le Corre $S$ and Chemineau $P$ Control of photoperiodic inhibition of luteinizing hormone secretion by dopaminergic and serotonergic systems in ovariectomized lle-de-France ewes supplemented with oestradiol. J Reprod Fertil 1993, 97:367-373

19. Le Corre S and Chemineau P Serotonergic 5HT2-receptors mediate the inhibitory action of serotonin on LH secretion in ovariectomized, estradiol-treated ewes that are refractory to short days. Biol Reprod 1993, 49: I 40-147

20. LeCorre S, Segu L, Caldani M and Chemineau P Differences in Ketanserin binding in the ventromedial hypothalamus of ewes responsive or refractory to short days. Neuroendocrinology 1994 , 60:589-600 
21. Pelletier J, Auzan C, Daveau A, Clauser E and Chemineau P Sheep $5 \mathrm{HT} 2_{A}$ receptors: partial cloning of the coding sequence and mRNA localization by in situ hybridization in the ewe hypothalamus. Cell Tissue Res 1999, 295:231-239

22. Goldman BD Mammalian photoperiodic system: formal properties and neuroendocrine mechanisms of photoperiodic time measurement. J Biol Rhythms 200I, 16:283-30 I

23. Schwartz WJ, de la Iglesia $\mathrm{HO}$, Zlomanczuk $\mathrm{P}$ and IIInerova $\mathrm{H}$ Encoding Le Quattro Stagioni within the mammalian brain: photoperiodic orchestration through the suprachiasmatic nucleus. J Biol Rhythms 200I, 16:302-31 I

24. Francois-Bellan AM and Bosler $O$ Convergent serotonin and GABA innervation of VIP neurons in the suprachiasmatic nucleus demonstrated by triple labeling in the rat. Brain Res 1992, 595: 149-153

25. Manrique $C$, Bosler $O$, Becquet D, Hery F, Faudon $M$ and FrancoisBellan AM Post-lesion up-regulation of 5-HTIB binding sites in the suprachiasmatic nucleus may be reversed after spontaneous or graft-induced serotonin reinnervation. Brain Res 1998, 788:332-336

26. Rea MA and Pickard GE A 5-HT(IB) receptor agonist inhibits light-induced suppression of pineal melatonin production. Brain Res 2000, 858:424-428

27. Zucker I, Boshes M and Dark J Suprachiasmatic nuclei influence circannual and circadian rhythms of ground squirrels. $\mathrm{Am} J$ Physiol 1983, 244:R472-480

28. Dark J and Zucker I Circannual rhythms of ground squirrels: role of the hypothalamic paraventricular nucleus. I Biol Rhythms 1985, I: 17-23

29. Dark J, Pickard GE and Zucker I Persistence of circannual rhythms in ground squirrels with lesions of the suprachiasmatic nuclei. Brain Res 1985, 332:201-207

30. Ruby NF, Dark J, Heller HC and Zucker I Ablation of suprachiasmatic nucleus alters timing of hibernation in ground squirrels. Proc Natl Acad Sci USA 1996, 93:9864-9868

31. Ruby NF, Dark J, Heller HC and Zucker I Suprachiasmatic nucleus: role in circannual body mass and hibernation rhythms of ground squirrels. Brain Res 1998, 782:63-72

32. Bae HH, Mangels RA, Cho BS, Dark J, Yellon SM and Zucker I Ventromedial hypothalamic mediation of photoperiodic gonadal responses in male Syrian hamsters. J Biol Rhythms 1999, I 5:391401

33. Freeman DA and Zucker I Refractoriness to melatonin occurs independently at multiple brain sites in Siberian hamsters. Proc Natl Acad Sci USA 2001, 98:6447-6452

34. Tillet $Y$ Immunocytochemical localization of serotonin-containing neurons in the myencephalon, brainstem and diencephalon of the sheep. Neuroscience 1987, 23:50I-527

35. Phelix CF, Adai DM, Cantu C, Chen H and Wayner MJ Immunohistochemical demonstration of serotonin-containing axons in the hypothalamus of the white-footed mouse, peromyscus leucopus. Brain Res 1998, 808:197-219

36. Kawata M, Takeuchi $Y$, Ueda S, Matsuura T and Sano Y Immunohistochemical demonstration of serotonin-containing nerve fibers in the hypothalamus of the monkey, Macaca fuscata. Cell Tissue Res 1984, 236:495-503

37. Steinbusch HWM and Nieuwenhuys R Localization of serotoninlike immunoreactivity in the central nervous system and pituitary of the rat with special references to the innervation of the hypothalamus. In Advances in Experimental Medical Biology (Edited by: Haber B, Gabey S, Issidorides MR, Alivesatos SGA) New York, Plenum 1981, 133:7-36

38. Abrahamson EE and Moore RY The posterior hypothalamic area : chemoarchitecture and afferent connections. Brain Res 200I, 889: $1-22$

39. Sakai K, Yoshimoto Y, Luppi PH, Fort P, el Mansari M, Salvert D and Jouvet $M$ Lower brainstem afferents to the cat posterior hypothalamus: a double-labelling study. Brain Res Bull 1990, 24:437-455

40. Malpaux B, Daveau A, Maurice-Mandon F, Duarte G and Chemineau $P$ Evidence that melatonin acts in the premammillary hypothalamic area to control reproduction in the ewe: presence of binding sites and stimulation of luteinizing hormone secretion by in situ microimplant delivery. Endocrinology 1998, 139:1508-1516
41. Migaud M, Nignol AC, Daveau A and Malpaux B Evidence for MtI melatonin receptor transcript expression in the ovine premammillary hypothalamus area. Society for Neuroscience, San Diego, California, USA Abst. 466.I2Nov 10-15 200I

42. Mailliet F, Audinot V, Delagrange P, Barrett P, Boutin J and Malpaux B Pharmacological characterization of melatonin binding sites in the ovine pre-mammillary hypothalamic area. Society for Neuroscience, San Diego, California, USA Abst. 184.2Nov 10-15 2001

43. Malpaux B, Migaud M, Tricoire $\mathrm{H}$ and Chemineau P Biology of mammalian photoperiodism and the critical role of the pineal gland and melatonin. J Biol Rhythms 200I, 16:336-347

44. Beltramino $C$ and Taliesnik $S$ Inhibitory influence of the nuclei of the posterior hypothalamus on the pro-oestrous surge of LH. Acta Endocrinol (Copenh) 1984, 105:433-440

45. Gundlah C, Pecins-Thompson M, Schutzer WE and Bethea CL Ovarian steroid effects on serotonin IA, $2 A$ and $2 C$ receptor mRNA in macaque hypothalamus. Brain Res Mol Brain Res 1999, 63:325-339

46. Anderson GM, Billings HJ, Connors JM, Goodman RL and Karsch FJ Thyroid hormones are required for the day-night rhythm of fos expression in the premammillary hypothalamus. Society for Neuroscience, New Orleans La, USA 26:1445 (abstract 540.II)4-9 November 2000

47. Uphouse L Multiple serotonin receptors: too many, not enough, or just the right number? Neurosci Biobehav Rev 1997, 21:679-698

48. Hoyer D, Hannon JP and Martin GR Molecular, pharmacological and functional diversity of 5-HT receptors. Pharmacol Biochem Behav 2002, 71:533-554

49. Johnson JH and Kitts CS Serotonergic mediation of a negative feedback effect of estrogen on luteinizing hormone release in ovariectomized rats. Endocrinology 1988, 1 23:2270-2275

50. Fink G, Dow RC, McQueen JK, Bennie JG and Carroll SM Serotonergic 5-HT2A receptors important for the oestradiol-induced surge of luteinising hormone-releasing hormone in the rat. I Neuroendocrinol 1999, I1:63-69

5I. Ziffa E and Fillion G 5-Hydroxytriptamine receptors. Pharmacol Rev 1992, 44:40I-456

52. Maes $M$ and Metlzer HY The serotonin hypothesis of major depression. In: Psychopharmacology: the fourth generation of progress (Edited by: Bloom FE, Kupfer DJ) New-York, Raven Press 1995, 933-944

53. Papolos DF, Yu YM, Rosenbaum E and Lachman HM Modulation of learned helplessness by 5-hydroxytryptamine2A receptor antisense oligodeoxynucleotides. Psychiatry Res 1996, 63:197203

54. Kulikov $A$, Moreau $X$ and Jeanningros $R$ Effects of experimental hypothyriodism on 5-HTIA, 5-HT2A receptors, 5-HT uptake sites and tryptophan hydoxylase activity in mature rat brain. Neuroendocrinology 1999, 69:453-459

55. Dahl GE, Evans NP, Moenter SM and Karsch FJ The thyroid gland is required for reproductive neuroendocrine responses to photoperiod in the ewe. Endocrinology 1994, 135:10-5

56. Dahl GE, Evans NP, Thrun LA and Karsch FJ Thyroxine is permissive to seasonal transitions in reproductive neuroendocrine activity in the ewe. Biol Reprod 1995, 52:690-696

57. Thrun LA, Dahl GE, Evans NP and Karsch FJ A critical period for thyroid hormone action on seasonal changes in reproductive neuroendocrine function in the ewe. Endocrinology 1997, 138:3402-3409

58. Viguié C, Battaglia DF, Krasa HB, Thrun LA and Karsch FJ Thyroid hormones act primarily within the brain to promote the seasonal inhibition of luteinizing hormone secretion in the ewe. Endocrinology 1999, 140: IIII-III7

59. Karsch FJ, Weick RF, Hotchkiss J, Dierschke DJ and Knobil E An analysis of the negative feedback control of gonadotropin secretion utilizing chronic implantation of ovarian steroids in ovariectomized rhesus monkeys. Endocrinology 1973, 93:478-86

60. Legan SJ, Foster DL and Karsch FJ The endocrine control of seasonal reproductive function in the ewe: a marked change in response to the negative feedback action of estradiol on luteinizing hormone secretion. Endocrinology 1977, 10 I:818-824

61. Karsch FJ, Dahl GE, Evans NP, Manning JM, Mayfield KP, Moenter SM and Foster DL Seasonal changes in gonadotropin-releasing hormone secretion in the ewe: alteration in response to the negative feedback action of estradiol. Biol Reprod 1993, 49: 1377 . 1383 
62. Dempsey RL, Hopkins J, Bittman EL and Kindt GW Total pinealectomy by an occipital parasagittal approach in sheep. Surg Neurol 1982, 18:377-380

63. Sibony M, Commo F, Callard P and Gasc JM Enhancement of mRNA in situ hybridization signal by microwave heating. Lab Invest 1995, 73:586-59|

64. Richard P Atlas stéréotaxique du cerveau de brebis Préalpesdu-Sud. Institut National de la Recherche Agronomique, Paris 1967,

65. Paxinos $G$ and Watson $C$ The rat brain in stereotaxic coordonates. Academic Press, New York 1982,

66. Pazos A, Cortés R and Palacios JM Quantitative autoradiographic mapping of serotonin receptors in the rat brain. II: serotonin-2 receptors. Brain Res 1985, 346:23 I-249

67. Segu $L$, Rage $P$ and Boulenguez $P$ A new system for computer-assisted quantitative receptor autoradiography. J Neurosci Methods 1990, 3 I: 197-205

68. Pelletier J, Garnier DH, de Reviers MM, Terqui M and Ortavant R Seasonal variation in $\mathrm{LH}$ and testosterone release in rams of two breeds. J Reprod Fertil 1982, 64:34I-346

69. Montgomery GW, Martin GB and Pelletier / Changes in pulsatile LH secretion after ovariectomy in Ile-de-France ewes in two seasons. J Reprod Fertil 1985, 73:173-183

70. Hauger RL, Karsch FJ and Foster DL A new concept for the control of the estrous cycle of the ewe based on the temporal relationships between luteinizing hormone, estradiol and progesterone in peripheral serum and evidence that progesterone inhibits tonic LH secretion. Endocrinology 1977, 10 1:807817

7I. Niswender GD, Midgley AR Jr and Reichert LE Jr Radioimmunologic studies with murine, ovine, and porcine luteinizing hormone. In: Gonadotropins (Edited by: Rosenberg E) Los Altos, CA: GERON$X 1968,299-306$

72. Niswender GD, Reichert LE Jr, Midgley AR Jr and Nalbandov AV Radioimmunoassay for bovine and ovine luteinizing hormone. Endocrinology 1968, 84: I I66-1I73

73. Wallace JM and McNeilly AS Changes in FSH and the pulsatile secretion of LH during treatment of ewes with bovine follicular fluid throughout the luteal phase of the oestrous cycle. J Endocrinology 1986, I I I:3 |7-327

74. Normolle DP and Brown MB Identification of aperiodic seasonality in non-Gaussian time series. Biometrics 1994, 50:798-812
Publish with Bio Med Central and every scientist can read your work free of charge

"BioMed Central will be the most significant development for disseminating the results of biomedical research in our lifetime. "

Sir Paul Nurse, Cancer Research UK

Your research papers will be:

- available free of charge to the entire biomedical community

- peer reviewed and published immediately upon acceptance

- cited in PubMed and archived on PubMed Central

- yours - you keep the copyright
BioMedcentral 